\title{
Five Years after: The Impact of Mass Privatization on Wages in Russia, 1993-1998
}

\author{
Elizabeth Brainerd ${ }^{1}$
}

\begin{abstract}
Williams College, Williamstown, Massachusetts 01267; Centre for Economic Policy Research, London, United Kingdom; Institute for the Study of Labor (IZA), Bonn, Germany; and William Davidson Institute, University of Michigan Business School, Ann Arbor
\end{abstract}

Received November 2, 2001; revised December 19, 2001

\begin{abstract}
Brainerd, Elizabeth-Five Years after: The Impact of Mass Privatization on Wages in Russia, 1993-1998

The mass transfer of enterprises from state to private hands in Russia is one of the most remarkable events of the past decade, yet little is known about how privatization has affected workers. This paper explores the effect of changing ownership on the wage distribution, focusing on how wage differentials between state-owned and privatized enterprises have evolved over the course of the transition. Privatized state enterprises paid higher wages than state enterprises in 1993 and 1998, but wages in the two sectors are similar in other years. In addition, wages in private firms exceed those in both state and privatized enterprises, but these wage differentials narrowed significantly between 1993 and 1998. J. Comp. Econ., March 2002, 30(1), pp. 160-190. Williams College, Williamstown, Massachusetts 01267; Centre for Economic Policy Research, London, United Kingdom; Institute for the Study of Labor (IZA), Bonn, Germany; and William Davidson Institute, University of Michigan Business School, Ann Arbor. (c) 2002 Elsevier Science (USA)
\end{abstract}

Journal of Economic Literature Classification Numbers: J31, P23, P31.

\section{INTRODUCTION}

The Russian program to privatize its state enterprises that began in June 1992 comprised one of the most ambitious efforts ever to effect a mass transfer of ownership from state to private hands. Mired in controversy from its inception, the

${ }^{1}$ I am grateful to Simon Commander, Jennifer Hunt, Hartmut Lehmann, Peter Murrell, Katherine Terrell, two anonymous referees, and seminar participants at the 2000 AEA meetings and the Conference on Labor Markets in Transition Economies, IZA, Bonn, May 2000, for helpful comments and suggestions. I also thank the Center for International Development at Harvard University for providing excellent research facilities while I was a visiting scholar there during 1999-2000, when much of the research for this paper was completed. 
program nevertheless succeeded in transferring a substantial share of enterprises out of the control of the state in a remarkably short time period. The speed and scale of Russia's mass privatization program were achieved in large part because the program allowed workers and managers to acquire significant stakes in their enterprises, a strategy that gained the support of an important segment of the population. In the immediate aftermath of the first phase of the mass privatization program, the dominant form of ownership in Russia was "insider" ownership.

A growing body of literature has examined the outcome of the mass privatization programs in Russia and other formerly socialist countries; this research has focused on the important question of whether the change in ownership leads to restructuring and enhances the efficiency of firms' operations. Analysts studying the impact of privatization on firms in developed countries similarly concentrate on the effects of privatization on firm efficiency as reflected in stock market performance, principalagent interactions, and product market performance. ${ }^{2}$ Relatively little research, either for transition economies or for other countries, has investigated the impact of privatization on labor market outcomes such as changes in the relative wages of workers in privatized firms. ${ }^{3}$

This paper explores the effect of mass privatization on the wage and skill distributions in Russia. It seeks to determine whether there is a wage differential between state-owned and privatized enterprises in Russia and, if so, how this wage differential has evolved over the course of the transition. This issue is important not only for understanding how privatization has affected workers and possibly contributed to growing wage inequality in Russia but also for assessing whether wage-setting behavior differs between state-owned and privatized enterprises. While previous research using firm-level data for Russia shows few differences in outcomes and restructuring between state and privatized enterprises - at least in the short term following privatization-it is possible that differences in wage-setting behavior between state and privatized enterprises exist and reflect emerging differences in firms' objective functions and constraints. ${ }^{4}$

The results indicate that workers in privatized enterprises indeed earned a positive wage premium relative to their state sector counterparts, but only in some phases of the privatization program. The evidence suggests that the distribution of skills and the returns to skills are similar between state and privatized firms, so one must search elsewhere for explanations of the wage premium in the privatized sector. Several possible sources of the wage differential are briefly explored: rent sharing between managers and workers in privatized firms; increased productivity due to restructuring; nonrandom selection of firms to be privatized, and self-selection of workers into privatized firms. The evidence on these issues is

${ }^{2}$ For a comprehensive survey of this literature, see Megginson and Netter (2001).

${ }^{3}$ One exception is Haskel and Szymanski (1993), who analyze the effects of privatization in the United Kingdom on wages and employment in privatized firms.

${ }^{4}$ Employment changes in privatized firms relative to state enterprises are also of interest but are not addressed in this paper due to lack of data on this issue. 
limited but suggests that the first explanation is more likely. Wages in new private sector firms are also examined and found to be substantially higher than wages in state-owned and privatized enterprises, but the differences narrowed significantly over the 1990's.

Several papers to date have analyzed state-private sector wage differentials in transition economies. Two of the earliest studies are those of Flanagan (1995) and Vecerník (1995), who analyze changes in wage differentials in the Czech Republic before and after the introduction of market reforms. Both conclude that private sector wages exceeded state sector wages in 1993 and 1994. Average wages are also higher in newly privatized state firms than in unprivatized state firms (Vecerník, 1995), but this differential disappears once one controls for differences in education and experience between the two types of ownership (Flanagan, 1995). Vecerník (1995) also shows that wage dispersion is higher in the private sector than in the state sector in the Czech Republic in these years.

Similar work has examined changes in the wage distribution in Poland before and after the "big bang" in 1990. Rutkowski (1996) uses official published data based on employer surveys to study changes in the wage distribution between 1987 and 1993. He concludes that private sector pay exceeded state sector pay in Poland in 1993 and that the wage distribution in the private sector was more disperse than that in the state sector. Newell and Socha (1998) use household survey data to compare changes in the Polish wage distribution between 1992 and 1996. While their analysis confirms that private sector monthly wages were higher than state sector wages in Poland in 1992, by 1996 this advantage had disappeared and state sector wages were slightly higher than private sector wages. Moreover, the authors show that if one controls for the difference in hours between the state and private sector, the private sector wage premium in Poland in 1992 disappears as well. Adamchik and Bedi (2000) also find that average wages in state sector firms exceeded those in private firms in Poland in 1996, but controlling for worker characteristics and selection into the private sector reverses the wage differential, with private sector wages $7 \%$ to $10 \%$ higher than wages in state enterprises. Lehmann and Wadsworth (2000) similarly document a 7\% wage premium in private sector firms in Poland during the mid-1990's, controlling for regional and demographic characteristics of workers. Their study also examines the private-state sector wage gap in Russia using the Russian Longitudinal Monitoring Survey (RLMS) and finds a private sector wage premium on the order of $13 \%$, which is nearly identical to the results presented in this paper using the same data set.

A related strand of literature analyzes the impact of privatization on firm behavior, particularly whether privatization, as intended, induces restructuring and enhances firm efficiency in Russia. Much of this literature is based on relatively small surveys of firms conducted during the mid-1990's; despite differences in samples and methodology, however, most studies conclude that privatization has had a negligible impact on firm behavior in Russia, at least during the years immediately following the implementation of the privatization program (Earle, Estrin, 
and Leshchenko, 1996; Filatotchev et al., 1996; Jones, 1998). ${ }^{5}$ These results concur with findings of a recent study of privatization in Poland, Hungary, and the Czech Republic that found that, while privatization to outside owners has a statistically significant impact on revenue and productivity, the performance of firms privatized to "insiders" is indistinguishable from that of state-owned enterprises (Frydman et al., 1999). A comprehensive analysis of the empirical literature on enterprise restructuring in transition similarly concludes that privatization to outsiders produces more restructuring than does privatization to insiders and that privatization is associated with more restructuring in non Commonwealth of Independent States (CIS) countries than in CIS countries (Djankov and Murrell, 2000). There is a consensus across studies that the dominant form of ownership in Russia is "insider ownership," although increasing proportions of shares are slowly being transferred from workers to managers and from workers to outside owners. A recent study confirms these conclusions and further shows that managers effectively collude with workers to preserve insider control (Filatotchev, Wright, and Bleaney, 1999).

\section{INSTITUTIONAL BACKGROUND: HOW RUSSIA WAS PRIVATIZED ${ }^{6}$}

When Russia became an independent state in late 1991, it inherited an economic structure in which nearly $85 \%$ of workers were employed in state-owned enterprises. Remarkably, by the end of the first phase of Russia's mass privatization program in mid-1994, more than two-thirds of the country's industry had been privatized and more than 40 million Russian citizens owned stock in firms or mutual funds. Given the country's starting point, the political opposition to the privatization program, and the continuing economic instability in the country, Russia's mass privatization program has been the most improbable component of its economic reform program. Its (relative) success was due to a mixture of factors, including the remarkable political skills of Anatoly Chubais, who headed the privatization program during the crucial early years; the recognition of the interests of managers, workers, and regional government leaders in the program; and a strong appeal to the public through the distribution of share vouchers and a well-crafted advertising campaign.

Russia's mass privatization program officially began on October 1, 1992, and its first stage concluded on July 1, 1994. The immediate goal of the program was to depoliticize state-owned firms, that is, to remove politicians' control over firms so that firm output and management practices would respond to the preferences of consumers and shareholders rather than to the preferences of politicians. Small firms (those with less than 200 employees and charter capital of less than 1 million rubles) were privatized through cash auctions or competitive tenders organized by

\footnotetext{
${ }^{5}$ Earle and Estrin (1998) is one of the few studies that finds that a higher share of private ownership in a firm is related to better firm performance and adjustment relative to state firms. For a comprehensive survey of this literature, see Estrin and Wright (1999).

${ }^{6}$ This description of the privatization program in Russia draws on Ash and Hare (1994); Bornstein (1994); Boycko, Shleifer, and Vishny (1995); and Frydman, Rapacznski, and Earle (1993).
} 
local governments. Under this program, by late 1994, $68 \%$ of retail trade firms, $70 \%$ of restaurants, and $78 \%$ of service establishments had been privatized. ${ }^{7}$

Medium-size and large enterprises were privatized through a more complex process. ${ }^{8}$ These firms were first corporatized, meaning they were reregistered as joint stock companies with $100 \%$ equity owned by the government and governed by a board of directors comprising management, workers, local government officials, and officials from the State Property Committee. Workers in the enterprise then voted on one of three possible "insider benefit" options. Under the first option, workers received $25 \%$ of (nonvoting) shares for free, with an option to buy $10 \%$ more shares at a nominal price. The second option was an employee-management buyout, in which management and workers could buy up to $51 \%$ of (voting) shares in the enterprise. Most enterprises (73\%) were privatized under this option, while $25 \%$ selected the first option. The remaining $2 \%$ were privatized under a third option that gave special responsibilities and privileges to a small group of insiders.

After corporatization, typically $29 \%$ of the enterprise's shares were then sold at a voucher auction. In late 1992, all Russian citizens received a voucher with a nominal value of 10,000 rubles (roughly the equivalent of the average monthly wage in the last quarter of 1992) that could be used to buy shares in one's own firm, in another firm at a voucher auction, or in a private voucher investment fund or that could be sold on the open market. More than 15,000 firms representing two-thirds of all eligible firms held voucher auctions in the first phase of the privatization program.

In the next phase of the privatization program, the remaining shares in the enterprise - the government stake-were sold through investment tenders to a core investor in exchange for a commitment to future investment in the company. This phase of the privatization program is ongoing but is proceeding at a slower pace than did the first phase of the program, and its effectiveness in enhancing corporate governance has been limited by the lack of transparency of the process in many cases and by the apparent ease with which well-connected parties are able to obtain stakes at below-market prices.

As a result of the first phase of the privatization program, by the end of 1994, more than two-thirds of all industrial enterprises were out of state hands and overall employment in state enterprises had fallen to $45 \%$ of total employment. Despite the rapid pace of the privatization program, however, some observers have argued that privatization has had little effect on firms' objectives and incentives to restructure. This sentiment is echoed by workers in privatized firms, who believe that privatization has had little influence on their firms.

Evidence on worker attitudes toward privatization is provided by a household survey conducted by the All-Russian Center for Public Opinion Research in

${ }^{7}$ For an analysis of small-scale privatization in Russia based on a survey of privatized shops, see Barberis et al. (1996).

${ }^{8}$ Firms in certain industries, such as rail transport, space exploration, and health and education, were prohibited from privatization. Privatization of firms in other sensitive areas, such as the armaments industry, the energy sector, and the communications industry, required a government decision. 
April 1994. This survey questioned 1597 workers, of whom $26.4 \%$ worked in firms that had gone through the privatization process. Most of the privatized firms were in industry $(68.9 \%)$ as well as in trade and public catering $(14.3 \%)$ and agriculture $(13.3 \%)$.

Few workers believed that privatization benefited either their firms or themselves personally. Of those employed in privatized firms, only $9.3 \%$ believed that privatization had improved the economic position of their firms. Many (42.0\%) believed that it had no influence, while nearly one-quarter believed that it had worsened the economic position of their firms. Similarly, only $11.2 \%$ of these workers believed that they had personally gained from their firms' privatization. Fully 20\% felt that they had lost personally; the majority believed that their position was unchanged. Monthly wages of workers in privatized firms in this sample $(143,378$ rubles/month) are slightly higher than those in state sector firms $(125,342$ rubles/month) but are lower than wages of workers in private sector firms (185,802 rubles/month).

\section{THEORETICAL FRAMEWORK}

Previous theoretical work on the impact of privatization on wages has shown that privatization may either increase or decrease wages, depending on the assumptions made regarding the firm's market power and objectives, worker bargaining power, and the nature of wage determination in the firm. Haskel and Szymanski (1993), for example, model privatization as a reduction in both union bargaining power and the firm's market power, so that privatization results in lower wages for workers. Goerke (1998), by contrast, shows that if state enterprises pay efficiency wages and if privatization increases the weight given to profit maximization in the firms' objective function, then privatization will lead to an increase in wages.

The key feature of privatization in Russia that an appropriate model will capture is the increase in worker power that resulted from insider privatization. Here, a simple model is sketched that takes this into account.

The state-owned enterprise is assumed to maximize a weighted average of profits and personal benefits to the politician or manager of the firm, where (for simplicity) personal benefits are assumed to depend only on employment in the enterprise:

$$
V=\gamma[p f(L)-w L]+(1-\gamma) B(L),
$$

where $p$ is the price of output, $\mathrm{f}(L)$ is a production function, $L$ is employment, $w$ is the wage, $B$ is the personal benefit accruing to the politician or manager controlling the firm, and $\gamma$ is the weight given to profit maximization. It is assumed that both state-owned enterprises and privatized firms have some market power, so that there is a possibility of rent sharing between the firm and workers. Due to the rules of privatization in Russia, it may be the case that state-owned enterprises have more market power than do privatized firms - especially as privatization progresses over 
time- but the implications of this difference are not explored here. ${ }^{9}$ The term $B(L)$, with $B^{\prime}(L)>0$, captures the possibility that a politician may gain the support of workers if they are employed by the firm (as in Shleifer and Vishny, 1994) or that managers may wish to employ additional workers for a variety of reasons: to have a ready supply of skilled workers should product demand recover; because managers perceive that this may help to obtain or maintain subsidies from the state; or because managers, for paternalistic reasons, wish to maintain excess employment.

The representative worker seeks to maximize utility that depends on the wage, the probability of employment in the firm, and the wage in alternative employment:

$$
U=e u(w)+(1-e) u\left(w_{a}\right)
$$

where $w$ is the wage paid by the firm, $w_{a}$ is the alternative wage, and $e$ is the probability of employment in the firm.

Given the perception that real wages in Russia are extremely flexible (Layard and Richter, 1995), it is plausible to assume that firms operate on the labor demand curve, in other words, that managers and workers bargain over wages but the firm sets employment given the wage. In this context, Russian workers have agreed to accept low wages in exchange for relatively high levels of employment. ${ }^{10}$

The generalized Nash bargaining solution of this "right-to-manage" model maximizes the weighted product of Eqs. (1) and (2), net of the alternative wage or profit earned if no agreement between the two parties is reached:

$$
\left.\operatorname{Max}_{w} U^{\beta} V=\left\{e\left[u(w)-u\left(w_{a}\right)\right]\right\}^{\beta}[\gamma p \mathrm{f}(L)-w L)+(1-\gamma) B(L)\right]^{1-\beta},
$$

where $\beta$ is the bargaining power of workers. Differentiating Eq. (3) with respect to $w$ and rearranging gives

$$
\frac{\beta e u^{\prime}(w)}{u(w)-u\left(w_{a}\right)}=\frac{(1-\beta) \gamma L}{\gamma(p \mathrm{f}(L)-w L)+(1-\gamma) B(L)} .
$$

Using the first-order approximation,

$$
\frac{u^{\prime}(w)}{u(w)-u\left(w_{a}\right)} \cong \frac{1}{w-w_{a}}
$$

${ }^{9}$ For an analysis of the impact of privatization, competition, and changing budget constraints on enterprises in Russia, see Earle and Estrin (1998).

${ }^{10}$ For a discussion of the right to manage versus the efficient bargaining model for Russia, see Luke and Schaffer (2000). 
and substituting $\pi=p \mathrm{f}(L)-w L$ and solving for $w$ gives

$$
w=w_{a}+\frac{\beta}{1-\beta}\left[\frac{\pi}{e}+\frac{(1-\gamma)}{\gamma} \frac{B(L)}{e}\right] .
$$

This expression shows that the wage depends positively on the outside wage, worker bargaining power, and profits and depends negatively on the weight the manager or politician assigns to profits. ${ }^{11}$

Several terms in this expression will change when a firm is privatized; clearly, $\beta$ increases because of the power gained by workers under insider privatization in Russia. This effect captures the possibility that, after privatization, managers will share rents with workers to gain their support. In addition, it is likely that privatization will result in an increase in the weight given to profit maximization in the firm's objective function. Because these two forces work in opposite directions on the wage, the impact of privatization on wages is theoretically ambiguous. If insider-owned firms put relatively little weight on profit maximization and their workers and managers take a short-term view of the firms' prospects, wages may be higher in these enterprises than in state enterprises as workers appropriate rents. On the other hand, greater emphasis on profits may reduce wages in privatized firms relative to state-owned firms.

Regarding wage differentials in new private sector firms, there are several reasons to expect that private sector wages might exceed wages of workers in state and privatized firms. First, if workers perceive that job security is more tenuous in private sector firms than in state sector firms, they may demand a wage premium for work in the private sector. Second, private firms may need to pay a higher wage to attract workers from the state sector, assuming that private firms are reluctant to hire from the pool of unemployed. Private firms may also pay efficiency wages to induce greater effort among the workforce.

\section{ECONOMETRIC AND DATA ISSUES}

While comparing wages across ownership types may seem a simple task, it is less straightforward than it appears. Ideally, one will control for differences in hours worked across the state, privatized, and new private firms as well as differences in nonwage compensation among the different types of firms. Data limitations, particularly regarding the latter issue, prevent a thorough analysis of these points, although to the extent possible they are addressed in the empirical work below. If possible, one should also distinguish between workers employed in privatized firms and workers employed in new private sector firms, but this distinction is unclear in one of the data sets used in this paper (the Russian Longitudinal Monitoring Survey).

11 This is similar to a model developed in Hildreth and Oswald (1997), which shows that, in an efficient bargaining framework, wages and profits per worker are positively related. 
Perhaps the most important difficulty one faces in estimating a state-privatized sector wage gap, however, is in accounting for issues of selection that are likely to affect the estimate. The ideal approach to investigating the effect of privatization on the wage structure is to randomly privatize firms; a simple comparison of mean wages in the two sectors then provides an unbiased estimate of the state-privatized sector wage differential. In Russia, however, firms were not randomly assigned to be privatized, and workers have been able to move freely between the state and privatized (and new private) sectors of the economy. In essence, not one but two selection problems may bias the results: the selection of enterprises to be privatized (e.g., perhaps better enterprises were privatized first) and the selection of workers into the state, privatized, or new private sector. Because workers and firms may be self-selected, simply comparing mean wages across sectors gives a biased estimate of the wage differential among state, privatized, and new private sector firms. One can argue that worker self-selection is likely to be negligible, at least in the early phase of the privatization program, because worker mobility was limited by the short time period in which to respond to wage differences, but certainly it may emerge as a factor during later years.

Several approaches (described below) are used in this paper to control for selection bias and to assess its effect on the state-privatized sector wage gap. While none of these approaches is ideal, all suggest that selection bias has little effect on the wage gap between workers in state and privatized firms. Selection bias is likely to be more important in explaining the substantial wage premium earned by workers in the new private sector, but few instruments are available for correcting the estimates for this effect.

The primary source of data for this analysis is a series of monthly household surveys conducted by the All-Russian Centre for Public Opinion Research (known as VTsIOM, its Russian acronym) in 1993, 1994, 1997, and 1998. VTsIOM was founded by the highly respected sociologist Tatiana Zaslavskaya during the mid1980's and has been conducting household surveys since 1989. A supplemental source of household survey data is provided by the second round of the Russian Longitudinal Monitoring Survey, a panel household survey conducted in 1994, 1995, 1996, and 1998. Both surveys are based on a three-stage stratified random sampling design in which the country is first stratified by large regions, primary sampling units are then selected from within the strata with probabilities proportionate to size, and households are randomly selected from rosters. The measure of wages used in both surveys is the wage received in the previous month after taxes. Because all surveys were conducted over the course of several months in each year, and for many years during the 1990's the Russian economy experienced high inflation, the monthly wages are deflated into consistent units within each survey using regional price indices (for 1993 and 1994) or the national consumer price index (for 1995-1998). For example, the 1993 VTsIOM surveys were conducted in March, April, May, and June of that year; the wages for these surveys are pooled and deflated into February 1993 rubles. A similar procedure is used for the other surveys. The samples analyzed in all surveys are men ages 18 to 59 years and 
women ages 18 to 54 years; this restricts the sample to the working-age population because the retirement age in Russia is 60 for men and 55 for women. The analysis also excludes self-employed individuals, people serving in the military, and individuals employed in nonprofit organizations such as political parties and trade union organizations. The goal of excluding the latter workers is to reduce the heterogeneity of the sample, in particular to better enable the comparison of wages in state enterprises and privatized enterprises. Finally, individuals who report earning less than one-half the minimum wage in the relevant month are also excluded from the sample; this eliminates the (relatively few) wage observations that appear to be coding errors.

The two surveys have a number of strengths and weaknesses. The advantages of the VTsIOM surveys include the relatively large sample size of the 1993 and 1994 surveys ( $N=8448$ and $N=4642$, respectively) and their reasonably good information on the type of ownership in the firm in which the respondent works. In particular, workers can select 1 of 12 types of ownership in the VTsIOM surveys, including whether the firm is a state-owned enterprise or a state joint stock company. For the purposes of this paper, it is assumed that state joint stock companies are enterprises in an early phase of privatization, that is, that they have been corporatized as described in Section 2 above. ${ }^{12}$ The primary disadvantages are that information on hours worked is not included in the surveys, so one cannot control for differences in hours between the state and private sectors, and the sample overrepresents highly educated individuals relative to the population as a whole. ${ }^{13}$ Because most workers are paid monthly in Russia, and part-time work is far less common than in, for example, the United States, the lack of data on hours worked is less problematic than it might be otherwise.

The RLMS, by contrast, appears to include a greater share of less educated individuals than do the VTsIOM surveys and is thus more representative in that sense. In addition, the data sets include information on hours worked, although this information is missing for about $10 \%$ of the observations. The RLMS also has several drawbacks. The industry classification of the enterprise the respondent works in is not publicly available in these surveys, so controls for this variable are excluded from the regressions. ${ }^{14}$ The crucial problem, however, is that one cannot distinguish between state firms and newly privatized state firms based on the ownership questions

${ }^{12}$ The Appendix provides the ownership questions asked in both the VTsIOM surveys and the RLMS. Note that while it would be of interest to examine the behavior of wages in de novo private sector firms, the ownership questions in both the VTsIOM surveys and the RLMS are insufficiently detailed to separate out these types of firms from other private firms.

${ }^{13}$ See Appendix Table 1, which shows the sex, age, education, and regional distribution of these surveys compared to these distributions tabulated from the 1994 Microcensus. Weights are used in the regression analysis to correct for this problem.

${ }^{14}$ Note that the state-private sector wage differential estimated using the RLMS data and presented in Table 3 (excluding industry controls) is nearly identical to that estimated in Lehmann and Wadsworth (2000) using the same data set with industry identifiers. As a result, industry affiliation appears to play little role in explaining the state-private sector wage differential in Russia. 
asked in the survey. Specifically, the respondent is asked three questions about the firms' ownership status: (1) Is the firm owned or co-owned by the state (yes/no)?, (2) Is the firm owned or co-owned by a Russian individual or group of individuals?, and (3) Is the firm owned or co-owned by a foreigner or group of foreigners? It is unclear from these questions to which category a respondent would assign a state joint stock company, and it is therefore impossible to distinguish workers in privatized firms in this data set. As a result, the RLMS analysis in this paper is based on only two categories of ownership; individuals are coded as working in a state enterprise if they replied "yes" to the state ownership question and are coded as working in the private sector if they answered "yes" to the second or third question. ${ }^{15}$ For the analysis based on the VTsIOM data, much of the empirical work divides ownership into three categories: individuals who work in state enterprises, those who work in state joint stock companies (i.e., privatized enterprises), and private sector workers. However, to enable comparisons with the RLMS, a "state-private" sector variable is defined as well, where individuals are coded as working in the state sector only if they answer "state enterprise" to the ownership question (i.e., state joint stock companies are coded as being in the private sector). Depending on how survey respondents interpret the state ownership question in the RLMS, therefore, the two definitions of the state and private sectors in the VTsIOM surveys and RLMS may encompass quite different forms of ownership.

Both the VTsIOM surveys and the RLMS share some problems in common. A difficult issue arising in any attempt to measure wages in Russia during the 1990 's is the problem of wage arrears and how to treat them in empirical work. Both surveys include questions regarding whether the respondent was affected by wage arrears, but insufficient information is provided to compute the contractual wage due the worker. While this problem is unlikely to greatly affect the 1993 survey because the scale of wage arrears was still relatively limited in that year, for subsequent years it is likely that this problem biases the sample. It does appear that workers in state and privatized enterprises are more likely to be affected by wage arrears than are private sector workers, although the latter group is far from immune from the problem. In particular, tabulations of the VTsIOM surveys indicate that in 1993, 5\% of workers in state enterprises reported that they received no wage in the previous month, compared to $8 \%$ of workers in privatized and private enterprises. By 1998, the scale of wage arrears had worsened significantly, with $35 \%$ of state sector workers, $38 \%$ of workers in privatized enterprises, and $29 \%$ of employees in private firms reporting that they received no pay in the previous month. If low-wage workers are more likely to be affected by wage arrears than are high-wage workers, as seems possible, then the higher incidence of wage arrears in state and privatized firms implies that wages in these enterprises may be overestimated relative to private sector wages and that the state-private wage

${ }^{15}$ Respondents who answer "yes" to the state ownership question and "yes" to either the Russian or foreign ownership question are coded as working in the private sector. 
differential discussed below is overestimated. Similarly, because in all years the proportion of workers in privatized enterprises reporting wage arrears (slightly) exceeds that in state enterprises, the state-privatized wage differential is likely biased downward. This issue should be kept in mind when interpreting the results presented below. ${ }^{16}$ In the regression analysis, all wage regressions include a dummy variable for whether or not the respondent is owed back wages by his or her enterprise, but this fails to circumvent the problem that individuals who did not get paid at all are excluded from the sample altogether.

A second issue that will affect the results for both surveys is the possibility that a worker misreports the ownership type of his or her firm. Given the speed and, at times, confusion with which the mass privatization program was implemented in Russia, it is likely that some workers were misinformed about the ownership status of their firms or that the ownership status of their firms was ambiguous during the privatization process itself. This will introduce measurement error into the regressions and will lead to attenuation bias in the coefficient estimates. ${ }^{17}$ Unfortunately, it is impossible to gauge the extent of this type of misclassification error based on currently available data.

\section{EMPIRICAL ANALYSIS}

\subsection{Changes in Ownership}

Russia's mass privatization program created a marked shift in the ownership structure of firms as intended. Figures 1 and 2 show the changes in ownership by number of enterprises and by employment, respectively, during recent years. As indicated in Fig. 1, by the beginning of 1998, fewer than 350,000 enterprises and organizations remained in state or municipal hands; this comprised $12.4 \%$ of all firms. Nearly three-quarters of firms were privately owned, while the remaining firms had a mixed form of ownership; this latter form mostly includes privatized state enterprises in which the state retains a stake in the charter capital (Gimpelson and Lippoldt, 1999). While such a high share of private ownership in the economy appears to indicate a stunning success of the privatization program, it should be noted that these official figures likely overestimate the share of the private ownership in the economy. ${ }^{18}$ Moreover, the distribution of employment by form of ownership differs markedly from the distribution of firms by form of ownership

\footnotetext{
${ }^{16}$ For further analysis of the wage arrears problem in Russia, see Earle and Sabirianova (1999) and Lehmann, Wadsworth, and Acquisti (1999).

${ }^{17}$ In other words, the coefficient estimate will be biased toward zero. Ownership status is a binary variable, and as a result, measurement error in this variable fails to satisfy the classical assumptions (i.e., a binary variable can be misclassified in only one of two ways, so that the error depends on the true value of the variable). However, Aigner (1973) shows that the coefficient estimate is still biased downward.

${ }^{18}$ This point is made by Gimpelson and Lippoldt (1999); the likely upward bias is due to the inclusion of old collective farms, leased enterprises, and other types of firms that are not purely private in the "private" category. For a careful discussion of the official statistics on private sector employment and an analysis of private sector employment in several regions of Russia in 1996, see their article.
} 


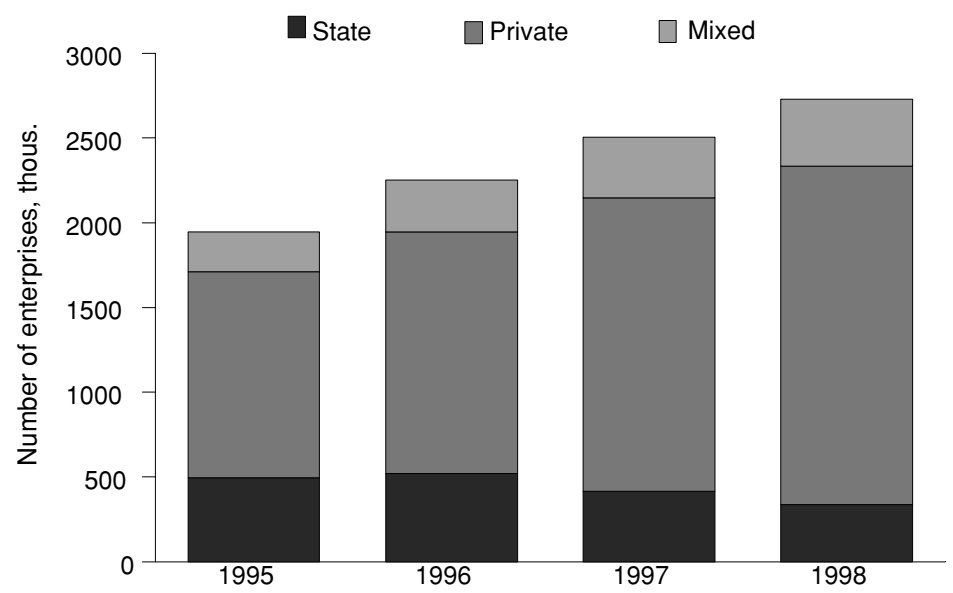

FIG. 1. Number of enterprises by form of ownership, 1995-1998, at beginning of year. The category "state" includes municipal enterprises; "mixed" includes privatized enterprises in which the state retains a stake in the charter capital and also includes social organizations and funds, joint ventures, and enterprises owned by foreign individuals.

Source. Goskomstat, Rossiiskii statisticheskii ezhegodnik (Russian Statistical Yearbook), 1998, p. 341 .

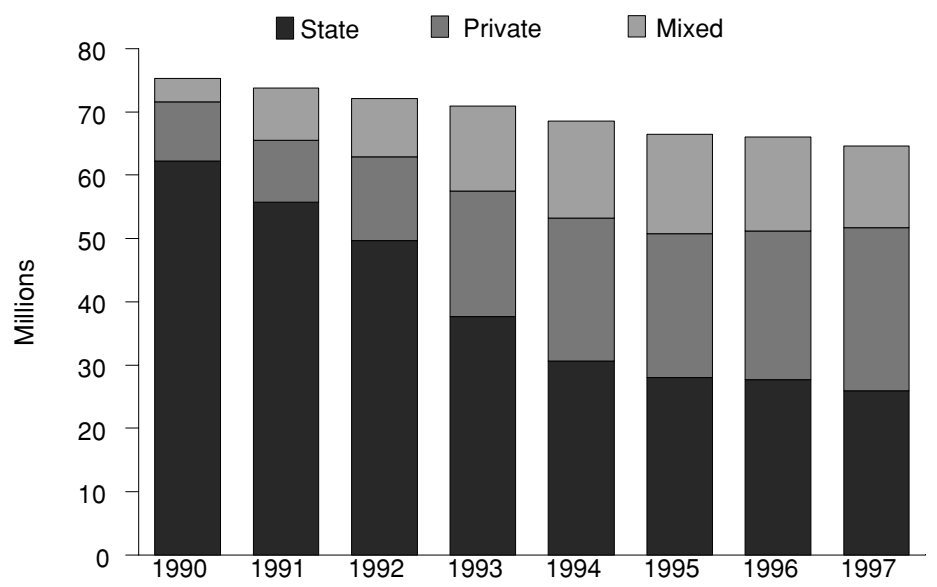

FIG. 2. Employment by form of ownership, 1990-1997. The category "state" includes municipal enterprises; "mixed" includes privatized enterprises in which the state retains a stake in the charter capital and also includes social organizations and funds, joint ventures, and enterprises owned by foreign individuals.

Source. Goskomstat, Rossiiskii statisticheskii ezhegodnik (Russian Statistical Yearbook), 1998, p. 178. 
(Fig. 2). While state sector employment fell sharply from its level of $82.6 \%$ in 1990 to $40.0 \%$ in 1997 , the latter figure is far greater than the $12.0 \%$ share of firms that remained state owned in 1997. The discrepancy between the employment share and the number of firms by type of ownership is due to the difference in firm size by type of ownership; state firms tend to be large enterprises comprising several hundred or several thousand workers, while private sector firms are much smaller on average, with less than 100 workers being the norm in this sector.

Table 1 describes the VTsIOM survey data by form of ownership and provides the official data on employment shares shown in Fig. 2 in the bottom panel for

TABLE 1

Distribution of Employed Workers by Type of Firm Ownership

(percentage of workers in each category)

\begin{tabular}{|c|c|c|c|c|}
\hline & 1993 & 1994 & 1997 & 1998 \\
\hline \multicolumn{5}{|l|}{ VTsIOM survey data $^{a}$} \\
\hline \multicolumn{5}{|l|}{ All workers } \\
\hline State enterprises & 64.3 & 55.2 & 51.8 & 49.3 \\
\hline State joint stock companies & 13.9 & 23.1 & 20.8 & 20.3 \\
\hline Private and other & 21.9 & 21.7 & 27.4 & 30.4 \\
\hline \multicolumn{5}{|l|}{ Men } \\
\hline State enterprises & 56.6 & 47.1 & 42.1 & 37.3 \\
\hline State joint stock companies & 15.0 & 25.8 & 24.5 & 25.7 \\
\hline Private and other & 28.4 & 27.1 & 33.4 & 37.1 \\
\hline \multicolumn{5}{|l|}{ Women } \\
\hline State enterprises & 70.3 & 61.6 & 59.8 & 58.9 \\
\hline State joint stock companies & 13.0 & 20.9 & 17.8 & 16.0 \\
\hline Private and other & 16.7 & 17.5 & 22.4 & 25.1 \\
\hline \multicolumn{5}{|l|}{ Sample $^{b}$} \\
\hline \multicolumn{5}{|l|}{ Percentages } \\
\hline State enterprises & 64.7 & 56.1 & 52.6 & 49.6 \\
\hline State joint stock companies & 14.0 & 22.6 & 18.1 & 19.2 \\
\hline Private and other & 21.4 & 21.4 & 29.4 & 31.1 \\
\hline Number of observations & 8,448 & 4,642 & 2,053 & 2,484 \\
\hline State enterprises & 5,463 & 2,603 & 1,079 & 1,233 \\
\hline State joint stock companies & 1,181 & 1,048 & 371 & 478 \\
\hline Private and other & 1,804 & 991 & 603 & 773 \\
\hline \multicolumn{5}{|l|}{ Official data ${ }^{c}$} \\
\hline \multicolumn{5}{|l|}{ All workers } \\
\hline State enterprises & 53.0 & 44.7 & 40.1 & 38.1 \\
\hline Mixed ownership & 17.6 & 21.1 & 18.3 & 16.4 \\
\hline Private and other & 29.4 & 34.2 & 41.6 & 45.5 \\
\hline
\end{tabular}

$a$ "Other" includes collective farms, consumer cooperatives, enterprises purchased by workers, leased enterprises, nonstate joint stock companies, and enterprises with participation of foreign capital.

${ }^{b}$ After elimination of observations with missing wages or other key variables.

c Source: Goskomstat, Rossiiskii statisticheskii ezhegodnik (Russian Statistical Yearbook), 2000, p. 112. 
TABLE 2

Wages by Type of Ownership

\begin{tabular}{lcccccc}
\hline & 1993 & 1994 & 1995 & 1996 & 1997 & 1998 \\
\hline VTsIOM data & & & & & & \\
$\quad$ Average monthly wages, rubles & & & & & & \\
$\quad$ State enterprises & 15,958 & 102,200 & na & na & 660,336 & 723,631 \\
$\quad$ State joint stock companies & 19,302 & 106,318 & na & na & 842,101 & 914,154 \\
$\quad$ Private and other & 33,308 & 159,664 & na & na & $1,302,977$ & $1,240,059$ \\
Monthly wage ratios: & & & & & & \\
$\quad$ State/state joint stock & 0.827 & 0.961 & na & na & 0.784 & 0.792 \\
$\quad$ State/private & 0.479 & 0.723 & na & na & 0.677 & 0.584 \\
RLMS data & & & & & & \\
$\quad$ State/private wages, monthly & na & 0.757 & 0.700 & 0.723 & na & 0.728 \\
Monthly hours, average & na & 160.9 & 168.3 & 169.7 & na & 167.2 \\
$\quad$ State & na & 158.2 & 165.7 & 165.2 & na & 160.6 \\
$\quad$ Private & na & 166.5 & 173.3 & 177.1 & na & 177.7 \\
$\quad$ Number reporting hours & & 3,075 & 2,622 & 2,152 & na & 2,329 \\
$\quad$ State/private wages, hourly, all & na & 0.833 & 0.640 & 0.813 & na & 0.837 \\
$\quad$ State/private wages, hourly, & na & 0.830 & 0.762 & 0.799 & na & 0.825 \\
$\quad$ workers working $>20$ hours & & & & & & \\
Sample (percentages) & & & & & & \\
$\quad$ State & na & 67.6 & 65.7 & 62.4 & na & 61.1 \\
$\quad$ Private and other & na & 32.4 & 34.3 & 37.6 & na & 38.9 \\
$\quad$ Total observations & na & 3,352 & 2,929 & 2,439 & na & 2,588 \\
\hline
\end{tabular}

Note. na, not available.

comparison; the distribution of employment by ownership type for the RLMS data is given in Table 2. While the survey data parallel the official data in showing a large decline in state sector employment and an increase in private sector employment between 1993 and 1998, the survey data indicate higher levels of state sector employment and substantially lower levels of private sector employment than do the official data. This is likely due, at least in part, to the private sector bias of the official data noted above as well as misreporting by survey respondents. The "true" amount of private sector employment may be impossible to measure precisely because of these problems as well as the blurring of ownership forms that seemed prevalent in the Russian economy of the 1990's. Table 1 also shows that employment by form of ownership differs markedly for men and women, with a higher share of women working in state sector firms and a higher share of men working in private sector firms.

\subsection{The State-Private Sector Wage Differential}

As noted above, an issue of central importance is the wage-setting behavior of newly privatized firms. These firms are likely to be similar in size, industrial distribution, and workforce composition to state enterprises-especially during the 
early years of the privatization program-so differences in wage-setting behavior between newly privatized and state firms may indicate that privatization has affected firm behavior.

The basic wage data for the VTsIOM surveys are presented at the top of Table 2. In all of the years represented in the table, the average monthly wage among workers in state enterprises is less than the average monthly wage for workers in state joint stock companies, which in turn is substantially less than the average monthly wage of workers in private sector firms. Workers in state enterprises earned 78\% to 83\% of the wages of their counterparts in state joint stock companies for most of the 1993 to 1998 period, although wages in the two sectors were nearly equal in 1994. The most dramatic difference in wages is between the state and private sector. State sector workers earned less than half of the wages of private sector workers in 1993; while this ratio rose during subsequent years, state sector workers still earned only $58 \%$ of the wages of private sector workers in 1998.

The RLMS, the second source of data used for this study, also indicates a substantial state-private sector wage gap, although it is slightly smaller than that suggested by the VTsIOM surveys. The ratio of state to private sector wages in that survey was 0.76 in 1994, compared to a ratio of 0.72 in the VTsIOM survey of the same year. This ratio declined to 0.70 in 1995 and averaged 0.73 over the four years (Table 2).

One source of the difference in wages between the state and private sectors is likely to be differences in hours worked; private sector workers probably work more hours on average than do those employed in the state sector. While one cannot address this issue using the VTsIOM data, the RLMS does query respondents on their usual monthly hours, enabling one to calculate hourly wages for workers in this survey. This is done at the bottom of Table 2, which also presents information on sample size and employment by sector for the RLMS. According to this survey, private sector workers do work more hours on average than state sector workers, and the difference has been increasing over time. Average hours in the state sector in 1994 were 158.2 per month, compared to 166.5 in the private sector, so that state hours were $95.0 \%$ of private hours; by 1998 , these figures were 160.6 and 177.7, respectively, so that state hours were only $90.4 \%$ of private hours. ${ }^{19}$ Even accounting for these differences in hours worked between the state and private sectors, however, a substantial gap in wages remains; the ratio of state to private sector average hourly wages was approximately $83.0 \%$ in most years of the RLMS.

Another potential source of compensation differences between the state and private sectors is in the provision of nonwage benefits to employees by firms. It is well-known that Russian enterprises have traditionally provided a wide array of services and benefits to their workers, either free of charge or at highly subsidized

\footnotetext{
${ }^{19}$ Note that roughly $10 \%$ of workers reporting positive wages in the RLMS failed to report hours worked, so that estimates of the wage gap based on hourly wages use fewer observations than those based on monthly wages and may be slightly biased from differential nonreporting between sectors.
} 
prices. These benefits include housing, medical services, vacations, day care, and subsidized food and other goods. While evidence suggests a modest reduction in these benefits by Russian firms as a whole over the course of the transition (Tratch, Rein, and Wörgötter, 1996; Rose, 1996), it is likely that the provision of such benefits differs between state and private sector firms. The VTsIOM surveys and RLMS cannot address this issue, but one survey of workers in 1995 indicated that workers in newly privatized firms received similar benefits to those in state firms, while workers in new private firms received many fewer benefits (Rose, 1996). It is unsurprising that state joint stock companies appear to be acting more like state enterprises in this sense because these enterprises, unlike new private sector firms, were already providing significant nonwage benefits to workers before they were privatized. If one were able to measure and value these nonwage benefits, it is possible that the total compensation of state firms by this measure would exceed the total compensation provided to workers by private firms. However, differential provision of nonwage benefits is unlikely to explain the state-privatized sector wage differential, at least during the early years of Russia's privatization program.

Returning to the state-private sector gap in wages, one can further explore this differential by estimating an ordinary least squares (OLS) log wage equation that includes a dummy variable for state sector employment. These regressions were estimated for each year of both surveys; the equations include controls for worker characteristics (education, potential experience and its square, gender, and whether the respondent was affected by wage arrears) and firm characteristics (industry [VTsIOM data only], firm size, and region), so that if the state-private wage differential is due, for example, to differences in the distribution of worker characteristics between the two sectors or to differences in the industrial or size distribution of firms, then the wage differential should be substantially reduced or eliminated in these regressions. The coefficients on the state sector variable in these regressions are given in Table 3 for both the VTsIOM and RLMS data sets. Although in both surveys the wage gap by this measure is smaller than the simple wage differences discussed earlier, there nevertheless remains a large and statistically significant difference between private and state sector monthly wages. The coefficient on the state sector variable is $-0.205(S E=0.040)$ in the 1993 VTsIOM survey and $-0.131(S E=0.040)$ in the 1994 RLMS. This coefficient falls to $-0.155(S E=0.052)$ in the 1998 VTsIOM survey and rises slightly to $-0.160(S E=0.036)$ in the 1998 RLMS. Using RLMS hourly wages, a statistically significant gap on the order of $10 \%$ remains between the state and private sectors in all years except 1996. Both surveys also show that the penalty for state sector employment is greater for women than for men in most years.

Turning to relative wages in state joint stock companies, the top of Table 4 shows the coefficients on state joint stock companies and private firms separately, with state sector firms the omitted variable. These results indicate that workers in state joint stock companies earned nearly $13 \%$ more than their state sector counterparts in 1993. Similar to the trends shown by the unadjusted wage differentials, the 
TABLE 3

Coefficient on State Sector Variable in Log Wage Regressions: VTsIOM Surveys and RLMS

\begin{tabular}{|c|c|c|c|c|c|c|}
\hline & 1993 & 1994 & 1995 & 1996 & 1997 & 1998 \\
\hline \multicolumn{7}{|l|}{$\operatorname{RLMS}^{a}$} \\
\hline OLS, monthly wages, all & - & $\begin{array}{c}-0.131^{* *} \\
(0.040)\end{array}$ & $\begin{array}{c}-0.165^{* *} \\
(0.043)\end{array}$ & $\begin{array}{c}-0.136^{* *} \\
(0.042)\end{array}$ & - & $\begin{array}{c}-0.160^{* *} \\
(0.036)\end{array}$ \\
\hline Men & - & $\begin{array}{r}-0.099 * \\
(0.051)\end{array}$ & $\begin{array}{c}-0.119^{* *} \\
(0.055)\end{array}$ & $\begin{array}{r}-0.090 \\
(0.059)\end{array}$ & - & $\begin{array}{r}-0.093^{*} \\
(0.055)\end{array}$ \\
\hline Women & - & $\begin{array}{c}-0.169^{* *} \\
(0.047)\end{array}$ & $\begin{array}{c}-0.219^{* *} \\
(0.049)\end{array}$ & $\begin{array}{c}-0.185^{* *} \\
(0.058)\end{array}$ & - & $\begin{array}{c}-0.245^{* *} \\
(0.054)\end{array}$ \\
\hline OLS, hourly wages, all & - & $\begin{array}{c}-0.091^{* *} \\
(0.038)\end{array}$ & $\begin{array}{c}-0.126^{* *} \\
(0.047)\end{array}$ & $\begin{array}{c}-0.064 \\
(0.044)\end{array}$ & - & $\begin{array}{c}-0.107^{* *} \\
(0.043)\end{array}$ \\
\hline \multicolumn{7}{|l|}{$\mathrm{VTsIOM}^{b}$} \\
\hline OLS, monthly wages, all & $\begin{array}{c}-0.205^{* *} \\
(0.040)\end{array}$ & $\begin{array}{c}-0.105^{* *} \\
(0.037)\end{array}$ & - & - & $\begin{array}{c}-0.149^{* *} \\
(0.053)\end{array}$ & $\begin{array}{c}-0.155^{* *} \\
(0.052)\end{array}$ \\
\hline Men & $\begin{array}{c}-0.246^{* *} \\
(0.043)\end{array}$ & $\begin{array}{c}-0.094^{* *} \\
(0.049)\end{array}$ & - & - & $\begin{array}{r}-0.097 \\
(0.065)\end{array}$ & $\begin{array}{r}-0.145^{*} \\
(0.075)\end{array}$ \\
\hline Women & $\begin{array}{c}-0.136^{* *} \\
(0.045)\end{array}$ & $\begin{array}{c}-0.119^{* *} \\
(0.044)\end{array}$ & - & - & $\begin{array}{c}-0.209^{* *} \\
(0.069)\end{array}$ & $\begin{array}{c}-0.161^{* *} \\
(0.056)\end{array}$ \\
\hline
\end{tabular}

${ }^{a}$ Regression of log wages on 5 categorical education variables, potential experience (age - years of education -7) and its square, a female dummy variable (for "all" regression), a dummy variable for whether the worker had wage arrears in the previous month, 7 regional dummy variables, and 5 firm-size variables (no industry controls). Standard errors are corrected for clustering within primary sampling units.

${ }^{b}$ The state sector is defined as state enterprises only (i.e., state joint stock companies coded as private firms). Controls include 6 categorical education variables, potential experience and its square, female dummy variable (for "all" regression), a dummy variable for whether the worker had wage arrears in the previous month, 6 or 9 industry variables, 5 firm-size variables, and 12 regional dummy variables. Standard errors are corrected for clustering within primary sampling units.

* Significant at the $10 \%$ level.

** Significant at the $5 \%$ level.

advantage in state joint stock company wages goes to zero in 1994, then rebounds again to $14 \%$ in 1998. A further comparison of wages between state and privatized enterprises is shown at the bottom of Table 4, which restricts the sample to industrial firms and excludes all private sector and other types of firms. Although previous regressions include controls for firm characteristics, this sample is limited to a homogeneous set of firms and may better control for unobserved firm characteristics than did the previous regressions. Nevertheless, the results are similar to those using the whole sample; workers in privatized enterprises earned a positive wage premium in 1993 and 1998, falling to zero in the interim years. The wage premium in the industrial enterprises is somewhat larger than that in the whole sample, at $17 \%$ to $18 \%$ in 1993 and 1998 .

By contrast, private sector workers earned a positive and statistically significant wage premium over state sector workers throughout the 1990's (top of Table 4). 
TABLE 4

Coefficient on Ownership Variables in Log Wage Regressions: VTsIOM Surveys

\begin{tabular}{|c|c|c|c|c|c|}
\hline & $\begin{array}{l}1993 \\
\text { OLS }\end{array}$ & $\begin{array}{c}1993 \\
\text { IV }\end{array}$ & $\begin{array}{l}1994 \\
\text { OLS }\end{array}$ & $\begin{array}{l}1997 \\
\text { OLS }\end{array}$ & $\begin{array}{l}1998 \\
\text { OLS }\end{array}$ \\
\hline \multicolumn{6}{|c|}{ Relative to the state sector ${ }^{a}$} \\
\hline State joint stock & $\begin{array}{c}0.125^{* *} \\
(0.042)\end{array}$ & $\begin{array}{c}0.828 \\
(1.03)\end{array}$ & $\begin{array}{c}0.005 \\
(0.040)\end{array}$ & $\begin{array}{c}0.065 \\
(0.070)\end{array}$ & $\begin{array}{c}0.143^{* *} \\
(0.056)\end{array}$ \\
\hline Private & $\begin{array}{l}0.271^{* *} \\
(0.048)\end{array}$ & $\begin{array}{l}.434^{* *} \\
(.214)\end{array}$ & $\begin{array}{c}0.234^{* *} \\
(0.044)\end{array}$ & $\begin{array}{c}0.210^{* *} \\
(0.065)\end{array}$ & $\begin{array}{c}0.165^{* *} \\
(0.074)\end{array}$ \\
\hline $\begin{array}{l}N \\
R^{2}\end{array}$ & $\begin{array}{c}8,448 \\
.237\end{array}$ & $\begin{array}{c}8,448 \\
.153\end{array}$ & $\begin{array}{c}4,642 \\
.346\end{array}$ & $\begin{array}{c}2,053 \\
.354\end{array}$ & $\begin{array}{l}2,484 \\
.402\end{array}$ \\
\hline \multicolumn{6}{|c|}{ Relative to the state sector, industrial enterprises only, excluding private sector firms ${ }^{b}$} \\
\hline State joint stock & $\begin{array}{l}0.181^{* *} \\
(0.042)\end{array}$ & $\begin{array}{c}1.88^{* *} \\
(0.857)\end{array}$ & $\begin{array}{c}0.035 \\
(0.048)\end{array}$ & $\begin{array}{c}0.037 \\
(0.083)\end{array}$ & $\begin{array}{c}0.165^{\text {** }} \\
(0.075)\end{array}$ \\
\hline$N$ & 3,324 & 3,324 & 1,590 & 585 & 496 \\
\hline$R^{2}$ & .237 & .195 & .279 & .309 & .388 \\
\hline
\end{tabular}

\footnotetext{
${ }^{a}$ Same controls as in Table 3.

${ }^{b}$ Same controls as in note $a$, except for industry controls.

** Significant at the $5 \%$ level.
}

The wage premium is large-roughly $27 \%$ in 1993 - but it narrows substantially over the years, falling to $16.5 \%$ by 1998 . This narrowing is unlikely to be due to declining hours worked by private sector workers relative to state sector workers because, as noted above and as demonstrated in Table 2, relative hours of private sector workers rose between 1994 and 1998. The falling wage premium in the private sector may reflect increased competition that has dissipated rents in the private sector and/or may be related to a changing skill mix of workers in the private sector as the private sector has expanded over the decade. As will be shown below, the latter may be a factor because the observable skills of workers in the private sector had converged slightly with those of workers in the state sector by 1998 .

\subsection{A Closer Look at the State-Privatized Sector Wage Gap}

Having established that there was a positive return to work in the privatized sector over the state sector in 1993 and 1998, a key issue is whether this premium is due to rent sharing with workers, increased productivity as a result of privatization, or worker or firm selection giving a biased estimate of the wage differential. Given the lack of enterprise information in these data sets, it is difficult to assess this issue empirically; it is also likely that the reason for the privatized sector wage premium in 1993 differs from that in 1998. In particular, worker self-selection and increased productivity due to privatization are less plausible explanations for the 1993 wage premium simply because the 1993 surveys were conducted in March through June of that year, an early phase of the privatization program, so that little restructuring or worker mobility is likely to have occurred by that point. 
It is possible that privatized firms had undertaken pre-privatization restructuring and that the enhanced productivity resulted in higher wages; however, (limited) evidence suggests that this is also not the case. A small subsample of the 1993 and 1994 VTsIOM surveys contained a question regarding whether the worker's enterprise was scheduled to be privatized in upcoming months (for 1993, $N=1452$; for $1994, N=532$ ); this allows one to compare wages in privatized enterprises to wages in firms that are due to be privatized in the near future. ${ }^{20}$ Although this technique fails to control for all forms of selection bias, it does control for the bias resulting if firms undertook pre-privatization restructuring and is appealing in the sense that it creates a control group that is similar to the firms that have been privatized. A comparison of mean wages between the two types of enterprises indicates that wages were slightly higher in both years in the firms that were due to be privatized, in 1993, for example, the average wage in privatized firms was 19,648 rubles, compared to 21,820 rubles in firms scheduled to be privatized. However, once one includes controls for the worker's education, gender, work experience, and region, the difference becomes statistically insignificant in both years. This suggests that enterprises undertook few productivity-enhancing measures prior to restructuring or that, if they did, the measures resulted in higher wages only with a lag.

As noted above, other types of selection bias may be at work. Better firms may be the ones to be privatized, or more skilled workers may have migrated from state to privatized firms seeking better opportunities. In either of these cases, the positive wage premium in the privatized sector relative to the state sector is overestimated, and one cannot interpret the higher wages in privatized firms as showing that privatization improves workers' wages. ${ }^{21}$

One approach to this problem is to find appropriate instruments for employment in the privatized sector. Two instruments are used here, both of which measure the speed with which privatization was implemented in each region of Russia. Because the implementation of the privatization program was largely devolved to Russia's regions, the speed with which a state enterprise was privatized depended at least in part on the region in which the enterprise was located rather than on the relative merits of the firm itself. ${ }^{22}$ As an example of the extreme divergence in the speed of privatization across regions, consider the statistics on the share of state enterprises converted to joint stock companies by June 1993 as a share of those slated for corporatization; the average share of enterprises corporatized across Russia was 49\% of those planned by June 1993. Only 2 of Russia's 89 regions had achieved $100 \%$ of planned corporatization, while no

${ }^{20}$ Frydman et al. (1999) use this technique to assess the impact of privatization on firm performance in Hungary, Poland, and the Czech Republic.

${ }^{21}$ Worker self-selection also likely affects the wage premium earned in the new private sector, but that issue is not explored in this paper because no suitable instruments for private sector employment appear to be available.

${ }^{22}$ Blanchard (1997) also makes this point. 
state enterprises at all had been corporatized in 3 regions. Only $2 \%$ of state enterprises had been converted into joint stock companies in Moscow (reflecting the slow pace of privatization in the capital city), while the surrounding area of Moscow oblast (region) had converted 61\% of its state enterprises by June 1993 (Slider, 1994). Given these differences, the speed of privatization across regions should be a suitable instrument because it is correlated with whether or not a worker is employed in a privatized firm, but is unlikely to be correlated with wages.

The instruments used here are the ratio of privatized enterprises to the prior total of state enterprises as of October 1993 in each region (as reported in Slider, 1994) and a dummy variable for a region that is not a republic (republics have greater autonomy than other regions and were slower to embark on their privatization programs); the city of Moscow is also coded as a republic due it its slow privatization speed. Both of these instruments are positively and significantly correlated with the likelihood that a worker was in a privatized enterprise in 1993, as indicated in the first-stage regressions.

Using these measures of speed as instruments, the coefficient on the state joint stock company variable is statistically insignificant in the 1993 regression on the entire sample of workers (Table 4). However, using the sample of workers in state or privatized industrial enterprises, the coefficient on the state joint stock company variable increases substantially in magnitude to 1.88 and is statistically significant at the $3 \%$ level (Table 4). Because correcting for firm or worker selection should reduce the estimated wage premium in privatized enterprises, the much higher instrumental variable (IV) estimates may indicate that this wage premium is not due to selection, at least in 1993. These results suggest that the OLS estimates are instead biased downward due to the probable measurement error in ownership status discussed previously. This interpretation is reinforced by the magnitude of the IV coefficient, which will be biased upward-sometimes a great deal-in the case of an endogenous dummy variable with measurement error. ${ }^{23}$ IV estimates for 1994 show insignificant (and large) coefficients-echoing the OLS results for 1993 - and could not be applied to the 1997 and 1998 surveys because the first-stage regressions showed the instruments to be weak for those years.

A final test of whether the wage differential between state and privatized enterprises is due to unobserved skill differences between workers is to examine the skill distribution of workers across sectors and whether this distribution is changing over time. If observed and unobserved skills are correlated, and if more highly skilled workers have migrated from state to privatized firms in search of better

${ }^{23}$ As demonstrated in Kane, Rouse, and Staiger (1999), instrumenting for an endogenous dummy variable with measurement error will bias the estimated IV coefficient upward, sometimes considerably. This is because, as noted in note 17, in a dummy variable the measurement error depends on the true value of the variable; because the IV is correlated with the true value, it will also be correlated with the measurement error. For a discussion of this and related issues, see also Angrist and Krueger (1999). 
TABLE 5

Multinomial Logit Regressions for Characteristics of Workers in Each Sector: VTsIOM Data

\begin{tabular}{lcccc}
\hline & 1993 & 1994 & 1997 & 1998 \\
\hline Relative to state sector & & & & \\
State joint stock companies & & & & \\
Years of education & -0.033 & -0.026 & -0.020 & -0.012 \\
& $(0.022)$ & $(0.027)$ & $(0.025)$ & $(0.016)$ \\
Age & $-0.007^{*}$ & 0.001 & -0.007 & -0.012 \\
& $(0.004)$ & $(0.005)$ & $(0.007)$ & $(0.010)$ \\
Female & 0.011 & 0.047 & 0.067 & -0.014 \\
& $(0.095)$ & $(0.117)$ & $(0.140)$ & $(0.252)$ \\
Private sector & & & & \\
Years of education & $0.079^{* *}$ & $0.092^{* *}$ & $0.074^{* *}$ & 0.005 \\
& $(0.022)$ & $(0.035)$ & $(0.023)$ & $(0.005)$ \\
Age & $-0.021^{* *}$ & $-0.022^{* *}$ & $-0.031^{* *}$ & $-0.032^{* *}$ \\
Female & $(0.005)$ & $(0.006)$ & $(0.006)$ & $(0.009)$ \\
& $-0.608^{* *}$ & $-0.408^{* *}$ & $-0.448^{* *}$ & $-0.761^{* *}$ \\
$N$ & $(0.091)$ & $(0.125)$ & $(0.124)$ & $(0.196)$ \\
& 8,448 & 4,642 & 2,053 & 2,484 \\
\hline
\end{tabular}

Note. Regressions also include 6 or 9 industry dummies and 11 regional dummies. Standard errors are corrected for clustering within primary sampling units.

* Significant at the $10 \%$ level.

** Significant at the $5 \%$ level.

opportunities, then this may account for the higher wages earned by workers in privatized enterprises in some years. As noted above, this is unlikely to be the case in the early years of privatization but may increasingly affect relative wages over time and may explain the positive wage premium in privatized enterprises in 1998.

It appears, however, that the distribution of workers by skill is similar in state and privatized enterprises not only in 1993 but through 1998 as well. This is shown in Table 5, which presents the results of multinominal logit regressions that compare the probabilities of different types of workers being in state joint stock companies and in the private sector relative to the state sector. Worker characteristics in state joint stock companies appear to differ little from worker characteristics in state enterprises; there is almost no difference in the distribution of education, experience, or gender between these two sectors, and this holds true for the entire 1993 to 1998 period (top of Table 5). If unobserved skills are correlated with these measured skills, then it is unlikely that the 1998 wage premium is due to more skilled workers moving to privatized firms. ${ }^{24}$ To summarize, this evidence

${ }^{24}$ Regressions of $\log$ wages on worker and firm characteristics by type of ownership indicate that the returns to skills (education and potential experience) are similar in state and privatized enterprises during years examined here. Returns to education are higher and returns to potential experience are lower in private firms than in state and privatized enterprises during the years studied here. (Results are available from the author on request.) 
suggests that the wage premia for privatized sector workers are not due to worker or firm selection or (at least in 1993) to enhanced productivity in privatized firms. It is possible that the wage premia are explained instead by rent sharing between workers and managers, which would be consistent with the insider method of privatization conducted in Russia.

As the bottom of Table 5 shows, there is a stark contrast in the characteristics of workers in state versus private sector firms; workers in the private sector are younger, more educated, and less likely to be women than are those in the state sector, and this is true for most of the period. If unobserved skills are correlated with these observed skills, then the wage premium for private sector work may reflect selection on unobserved skills. The narrowing of the wage premium for private sector employment may be due in part to the change in the skill distribution in the private sector in 1998, when the education level no longer exceeds that in the state sector, and could also reflect dissipating rents in the private sector over time.

\subsection{Quantile Regression Estimates of the State-Private \\ Sector Wage Differential}

The similarity of workers in state and privatized firms is also apparent in quantile regressions, which indicate how the privatized or private sector premium changes across deciles of the wage distribution. Because OLS estimates of the mean stateprivate sector wage differential may be misleading if the penalty varies depending on the position of the workers in the wage distribution, quantile regression techniques can provide a clearer picture of whether and how wage premia vary by skill; quantile regressions are also advantageous because they are less sensitive to outliers than the OLS regressions. This technique is implemented by estimating a log wage regression like those discussed above for the 1st through 9th quantiles and minimizing the sum of absolute deviations of the residuals; bootstrapped standard errors based on 100 repetitions are calculated to allow for possible heteroskedasticity of the residuals.

Figures 3 and 4 summarize the results of quantile regressions estimated using the VTsIOM surveys, with Fig. 3 presenting the returns to employment in private sector firms relative to state enterprises and Fig. 4 indicating the returns to employment in state joint stock companies relative to state enterprises. All regressions include controls for education, experience, gender, wage arrears, industry, and region as described in note $b$ of Table 3. The lightly shaded areas in Figs. 3 and 4 represent \pm 1 (bootstrapped) standard error around the coefficient estimate, which is given by the middle line between the two shaded areas. For example, the coefficient on private sector employment (relative to state employment) in 1993 at the 1st quantile is 0.165 , with a standard error of 0.039 .

Turning first to the premium for private sector work illustrated in Fig. 3, the most striking result is the monotonic increase in the return to private sector employment across the deciles of the wage distribution. While individuals in the $1 \mathrm{st}$ through $3 \mathrm{rd}$ deciles earned about a $16 \%$ premium for private sector work in 1993, individuals 

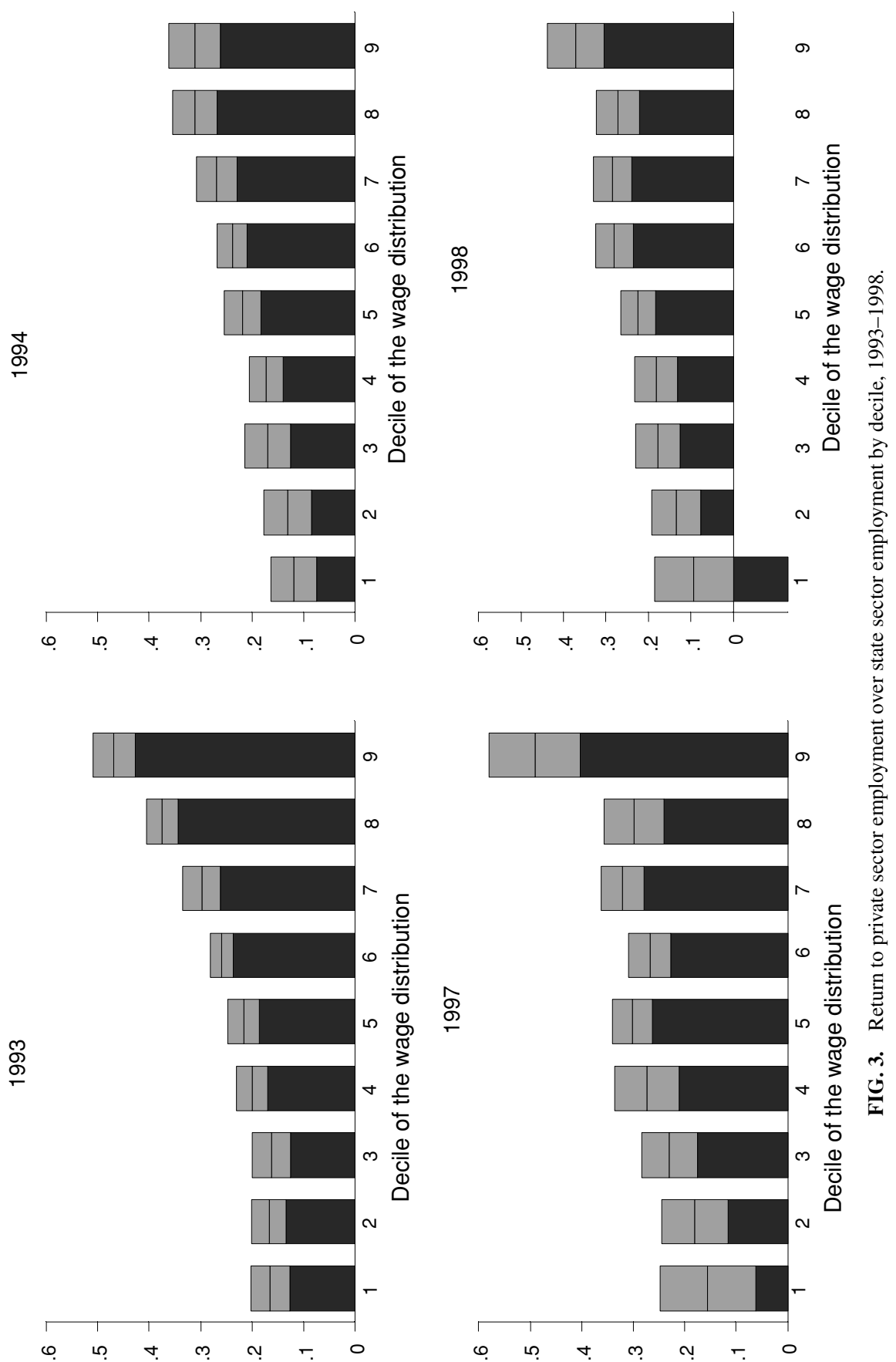

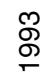

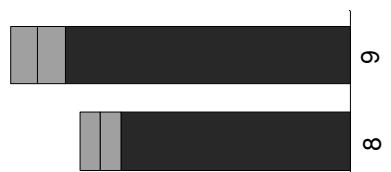

の

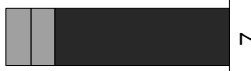

0 人 듬

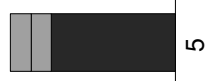

임

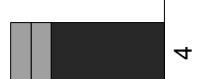

3

$\stackrel{9}{上}$

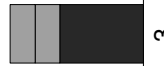

๓ $\frac{\Phi}{\bar{d}}$

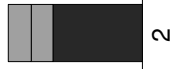

N

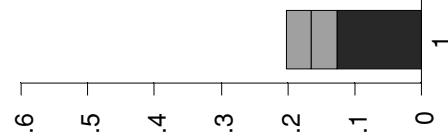

$\infty$
$\frac{\sigma}{1}$
2
2
$\frac{0}{0}$
$\frac{0}{0}$
$\frac{0}{2}$

ت

ह 
壴
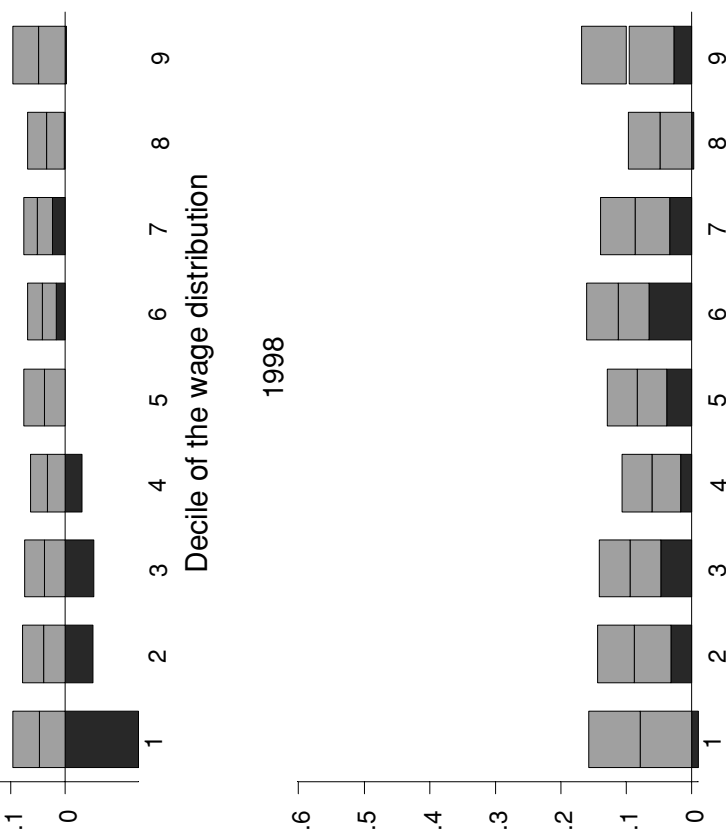

ำ

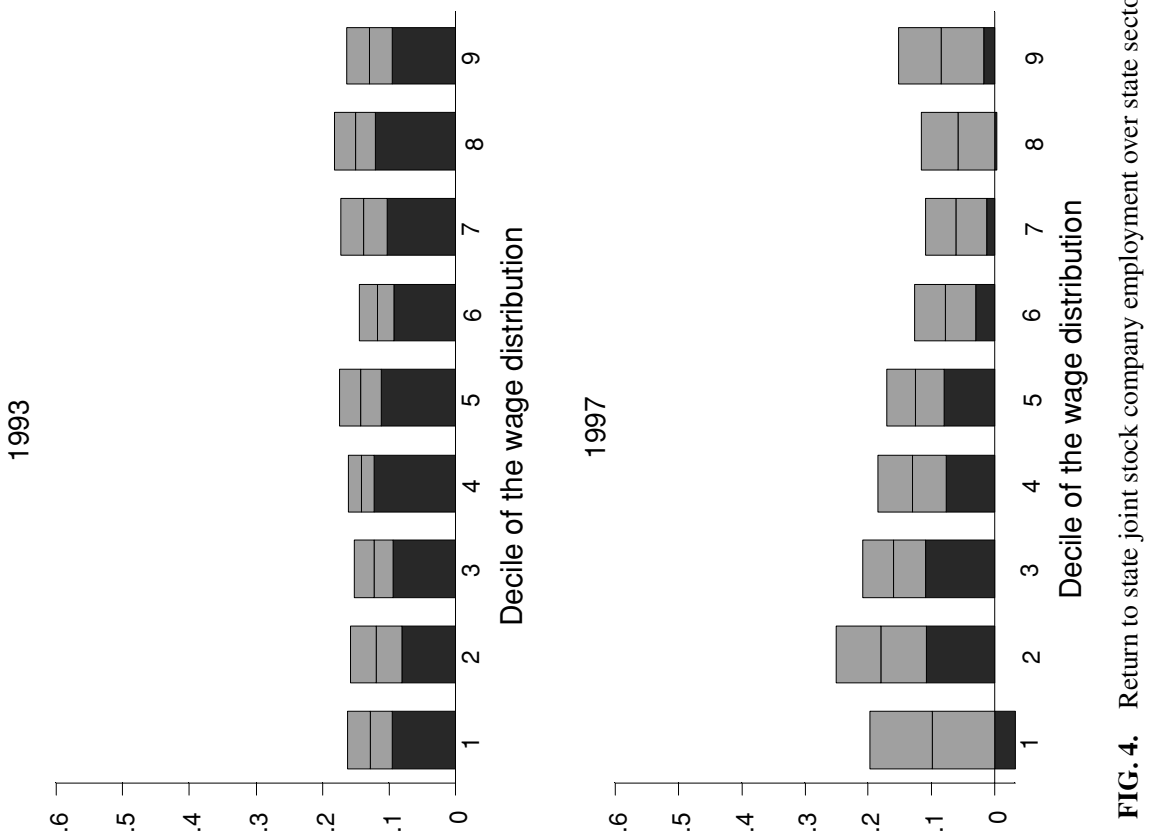

กิ

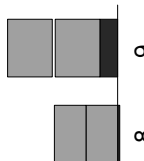

뭉
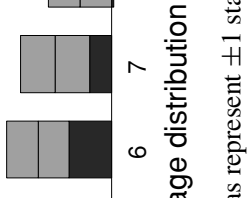

एँ

音
+0
0 บั

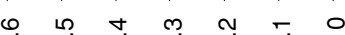

ल

ล

$\frac{\oplus}{\tilde{D}}$

훌 
in the 9th decile earned a premium of $47 \%$, even after including numerous controls for worker and firm characteristics. If a worker's wage is interpreted as a measure of skill, then this result indicates that the private sector wage premium increases with skill; the least skilled workers earn a small but positive wage premium for work in the private sector, and the most skilled workers earn a substantial premium. This relationship is particularly strong during the early stages of Russia's reforms but still appears to hold during the late 1990's, even though the average wage differential is narrowing over the period.

In contrast to the striking relationships shown in Fig. 3, there is no such pattern of increasing returns across quantiles for workers employed in state joint stock companies (Fig. 4). While there is a positive return to state joint stock company employment over state employment in 1993 and 1998, as in the OLS regressions, the return varies little across quantiles. In other years the effect is mostly statistically insignificant and appears unrelated to the quantile of the wage distribution.

These results imply that, whatever the cause of the wage premia for workers in privatized enterprises in 1993 and 1998, this cause had similar effects across all parts of the wage distribution. By contrast, the cause of the wage premia for private sector workers led to a consistent pattern of increasing returns for more skilled workers across the wage distribution. In other words, the quantile regression evidence suggests that two different explanations are required for the privatized and private sector wage premia during the 1990's. The increasing return to private sector employment across quantiles might reflect worker self-selection, if the most able workers self-select into the highest paying firms, while the constant wage premium across quantiles in privatized firms may be more consistent with a rent-sharing explanation, as managers simply increase all workers' wages to gain worker support. Because this pattern of wage premia across quantiles remains the same over the entire 1993 to 1998 period, there is little evidence that wage setting is changing in privatized firms over time to provide greater rewards to more productive workers as one might expect would be the case if privatization fundamentally changed firm behavior.

\subsection{Wage Dispersion across Ownership Types}

The final question to be addressed is whether privatization has contributed to increased wage inequality in Russia. As is now well-known, wage and income inequality increased dramatically in Russia after wages and prices were freed from administrative control in 1992; the levels of wage and income inequality in Russia are now among the highest in the world (Brainerd, 1998; Milanovic, 1999). Did the privatization of state enterprises exacerbate the increase in wage inequality? To investigate this issue, Table 6 presents various measures of wage dispersion across ownership types based on the VTsIOM surveys. These measures indicate that the dispersion in wages is substantially higher among private sector workers than among either state sector or state joint stock company workers. The RLMS data also show higher inequality among private sector workers than among state sector workers (not shown), and both surveys show some convergence in this over time, 


\section{TABLE 6}

Wage Dispersion by Type of Ownership: VTsIOM Surveys (differences in log monthly wages at various percentiles of the wage distribution)

\begin{tabular}{|c|c|c|c|c|}
\hline & 1993 & 1994 & 1997 & 1998 \\
\hline \multicolumn{5}{|l|}{ All workers } \\
\hline $90-10$ & 1.898 & 1.930 & 1.897 & 1.985 \\
\hline $90-50$ & 0.945 & 0.986 & 0.937 & 0.944 \\
\hline $50-10$ & 0.953 & 0.944 & 0.960 & 1.041 \\
\hline Standard deviation & 0.782 & 0.772 & 0.809 & 0.813 \\
\hline$N$ & 8,448 & 4,642 & 2,053 & 2,484 \\
\hline \multicolumn{5}{|l|}{ State enterprises } \\
\hline $90-10$ & 1.778 & 1.792 & 1.808 & 1.991 \\
\hline $90-50$ & 0.857 & 0.916 & 0.916 & 0.927 \\
\hline $50-10$ & 0.920 & 0.875 & 0.891 & 1.064 \\
\hline Standard deviation & 0.698 & 0.687 & 0.701 & 0.741 \\
\hline$N$ & 5,463 & 2,603 & 1,079 & 1,233 \\
\hline \multicolumn{5}{|c|}{ State joint stock companies } \\
\hline $90-10$ & 1.773 & 2.017 & 1.661 & 1.746 \\
\hline $90-50$ & 0.841 & 0.950 & 0.786 & 0.765 \\
\hline $50-10$ & 0.932 & 1.067 & 0.875 & 0.981 \\
\hline Standard deviation & 0.725 & 0.794 & 0.741 & 0.709 \\
\hline$N$ & 1,181 & 1,048 & 371 & 478 \\
\hline \multicolumn{5}{|l|}{ Private and other } \\
\hline $90-10$ & 2.418 & 2.293 & 2.283 & 2.037 \\
\hline $90-50$ & 1.328 & 1.161 & 1.139 & 1.045 \\
\hline $50-10$ & 1.090 & 1.133 & 1.143 & 0.992 \\
\hline Standard deviation & 0.988 & 0.915 & 0.951 & 0.921 \\
\hline$N$ & 1,804 & 991 & 603 & 773 \\
\hline
\end{tabular}

with state sector inequality increasing and private sector inequality decreasing slightly over the 1990's. Comparing wage inequality between state enterprises and state joint stock companies, however, the dispersion appears to be roughly similar across the two sectors in the years examined here. The similarity in wage dispersion between the state and privatized sectors indicates that privatization, in and of itself, has contributed little to rising wage inequality in Russia.

\section{CONCLUSION}

The privatization process in Russia has been a highly politicized and controversial operation, and public support for the program has waned during recent years as new revelations about questionable practices appear with growing frequency in the media. But the true test of whether Russia's privatization program has succeeded or failed lies in the impact of privatization on firms. Privatization was intended to change state enterprises from inefficient firms dependent on subsidies and indifferent to consumer needs into restructured competitive enterprises independent of the state in all senses. While evidence based on enterprise surveys indicates 
little change in firm behavior to date relative to state enterprises, this paper indicates that average wages in privatized firms are higher than in state enterprises in two of the four years examined here. The limited evidence on pre-privatization restructuring and worker self-selection considered here suggests that these fail to explain the privatized sector wage premia; the evidence appears to be more consistent with rent sharing within insider-owned firms as managers buy the collusion of workers. Overall, however, there is little evidence that wage setting in privatized firms has changed to provide greater rewards for more productive workers. A more promising indicator is the narrowing of the private sector wage premium over the 1990's, which may reflect reduced rents, greater competition, and expansion of the private sector over the period.

\section{APPENDIX}

Ownership Questions in VTsIOM Surveys and RLMS

VTsIOM Surveys

To which type of enterprise or organization does your primary place of work belong? (give one answer)

1. State enterprise or organization (including military and administrative organs)

2. State joint stock company

3. Kolkhoz, consumers' cooperative

4. Enterprise purchased by workers

5. Leased enterprise

6. Nonstate joint stock company

7. Enterprise belonging to one individual or several individuals (including partnerships and cooperatives)

8. Enterprise with participation of foreign capital

9. Foreign enterprise

10. Social organization (fund, party, movement, trade union, etc.)

11. Self-employed

12. Other

(Note that military employees are excluded from the surveys based on a different question in which the worker indicates the branch of employment.)

\section{RLMS}

Is the government the owner or co-owner of your enterprise or organization? (yes/no)

Tell me, please, is the place where you work owned or co-owned by foreign firms or foreign individuals? (yes/no)

Tell me, please, do any Russian individuals or private firms own or co-own your organization or enterprise? (yes/no) 
APPENDIX TABLE 1

Representativeness of VTsIOM Surveys

\begin{tabular}{|c|c|c|c|c|c|}
\hline & 1993 & 1994 & 1997 & 1998 & $\begin{array}{c}1994 \\
\text { Microcensus }^{a}\end{array}$ \\
\hline Percentage male & 39.5 & 39.8 & 41.9 & 40.8 & 45.9 \\
\hline Percentage female & 60.5 & 60.2 & 58.1 & 59.2 & 54.1 \\
\hline \multicolumn{6}{|c|}{ Population age 20 years or over } \\
\hline $20-29$ & 19.8 & 20.1 & 20.0 & 19.2 & 18.7 \\
\hline $30-39$ & 24.6 & 25.7 & 21.4 & 20.6 & 22.9 \\
\hline $40-49$ & 21.7 & 21.8 & 21.5 & 22.2 & 18.4 \\
\hline $50-59$ & 15.2 & 14.6 & 15.8 & 15.9 & 16.1 \\
\hline 60 years or over & 18.7 & 17.8 & 21.4 & 22.1 & 23.9 \\
\hline \multicolumn{6}{|c|}{ Education (age 15 years or over) } \\
\hline Higher & 21.8 & 20.9 & 21.5 & 21.2 & 13.3 \\
\hline Incomplete higher & 3.2 & 3.4 & 4.2 & 4.1 & 1.8 \\
\hline Secondary specialized & 26.1 & 27.8 & 27.5 & 28.0 & 21.9 \\
\hline Secondary & 27.6 & 28.5 & 26.5 & 27.3 & 28.5 \\
\hline Incomplete secondary & 14.1 & 13.3 & 12.6 & 12.6 & 20.2 \\
\hline Primary or less & 7.1 & 6.2 & 7.6 & 5.9 & 14.3 \\
\hline \multicolumn{6}{|l|}{ Regional distribution } \\
\hline North & 3.4 & 4.7 & 5.6 & 4.9 & 4.1 \\
\hline Northwest & 9.3 & 5.8 & 3.4 & 3.4 & 5.5 \\
\hline Central & 26.7 & 20.4 & 30.9 & 30.5 & 20.2 \\
\hline Volga-Vyatsky & 5.1 & 5.8 & 5.1 & 5.1 & 5.7 \\
\hline Central Chernozem & 4.7 & 5.3 & 4.8 & 4.6 & 5.3 \\
\hline Povolzhsky & 9.8 & 11.3 & 9.8 & 9.8 & 11.3 \\
\hline North Caucuses & 10.1 & 11.3 & 10.2 & 9.8 & 11.8 \\
\hline Urals & 11.3 & 14.6 & 12.1 & 12.1 & 13.8 \\
\hline West Siberia & 9.0 & 10.1 & 7.9 & 8.8 & 10.2 \\
\hline East Siberia & 6.0 & 5.8 & 5.6 & 5.4 & 6.2 \\
\hline Far East & 4.6 & 5.0 & 4.7 & 5.3 & 5.3 \\
\hline
\end{tabular}

a Source: Goskomstat (1995).

\section{REFERENCES}

Adamchik, Vera A., and Bedi, Arjun S., "Wage Differentials between the Public and the Private Sectors: Evidence from an Economy in Transition.” Labour Econ. 7, 2:203-224, Mar. 2000.

Aigner, Dennis J., "Regression with a Binary Independent Variable Subject to Errors of Observation." J. Econometrics 1, 1:49-59, Mar. 1973.

Angrist, Joshua D., and Krueger, Alan B., "Empirical Strategies in Labor Economics.” In Orley Ashenfelter and David Card, Eds., Handbook of Labor Economics, Vol. 3, pp. 1277-1366. Amsterdam: Elsevier Science, 1999.

Ash, Timonthy N., and Hare, Paul G., "Privatisation in the Russian Federation: Changing Enterprise Behaviour in the Transition Period." Camb. J. Econ. 18, 6:619-634, Dec. 1994.

Barberis, Nicholas, Boycko, Maxim, Shleifer, Andrei, and Tsukanova, Natalia, "How Does Privatization Work? Evidence from the Russian Shops.” J. Polit. Econ. 104, 4:764-790, Aug. 1996.

Blanchard, Olivier, The Economics of Post-Communist Transition. Oxford, UK: Oxford Univ. Press, 1997. 
Bornstein, Morris, "Russia's Mass Privatisation Programme." Communist Economies \& Economic Transformation 6, 4:419-457, 1994.

Boycko, Maxim, Shleifer, Andrei, and Vishny, Robert. Privatizing Russia. Cambridge, MA: MIT Press, 1995.

Brainerd, Elizabeth, "Winners and Losers in Russia's Economic Transition.” Am. Econ.Rev. 88, 5:10941116, Dec. 1998.

Djankov, Simeon, and Murrell, Peter, "Enterprise Restructuring in Transition: A Quantitative Survey." Typescript. Washington, DC: World Bank and University of Maryland, Nov. 2000.

Earle, John S., and Estrin, Saul, "Privatization, Competition, and Budget Constraints: Disciplining Enterprises in Russia." Stockholm Institute of Transition Economics Working Paper no. 128. Stockholm: SITE and East European Economies, Mar. 1998.

Earle, John S., Estrin, Saul, and Leshchenko, Larisa, "Ownership Structures, Patterns of Control, and Enterprise Behavior in Russia." In Simon Commander, Qimiao Fan, and Mark Schaffer, Eds., Enterprise Restructuring and Economic Policy in Russia, pp. 205-252. Washington, DC: Economic Development Institute, 1996.

Earle, John S., and Sabirianova, Klara, "Understanding Wage Arrears in Russia." Working Paper no. 139. Stockholm: Stockholm School of Economics, Jan. 1999.

Estrin, Saul, and Wright, Mike, "Corporate Governance in the Former Soviet Union: An Overview." J. Comp. Econ. 27, 3:398-421, Sept. 1999.

Filatotchev, Igor, Buck, Trevor, Grosfeld, Irena, Karsai, Judit, and Wright, Mike, "Buy-Outs in Hungary, Poland, and Russia: Governance and Finance Issues." Econ. Transition 4, 1:67-88, May 1996.

Filatotchev, Igor, Wright, Mike, and Bleaney, Michael, "Privatization, Insider Control, and Managerial Entrenchment in Russia." Econ. Transition 7, 2:481-504, 1999.

Flanagan, Robert J., "Wage Structures in the Transition of the Czech Economy." International Monetary Fund Staff Papers 42, 4:836-854, Dec. 1995.

Frydman, Roman, Gray, Cheryl, Hessel, Marek, and Rapaczynski, Andrzej, "When Does Privatization Work? The Impact of Private Ownership on Corporate Performance in the Transition Economies." Q.J.Econ. 114, 4:1153-1191, Nov. 1999.

Frydman, Roman, Rapaczynski, Andrzej, and Earle, John S., The Privatization Process in Russia, Ukraine, and the Baltic States. Budapest: Central European Univ. Press, 1993.

Gimpelson, Vladimir, and Lippoldt, Douglas, "Private Sector Employment in Russia." Econ. Transition 7, 2:505-533, 1999.

Goerke, Laszlo, "Privatization and Efficiency Wages.” J. Econ. 67, 3:243-264, 1998.

Goskomstat of Russia, Osnovnye Itogi Mikroperepisi Naseleniya $1994 \mathrm{~g}$ (Basic Results of the 1994 Microcensus of the Population). Moscow: Goskomstat, 1995.

Goskomstat of Russia, Rossiiskii statisticheskii ezhegonik 1998 (Russian Statistical Yearbook 1998). Moscow: Goskomstat, 1998.

Goskomstat of Russia, Rossiiskii statisticheskii ezhegonik 2000 (Russian Statistical Yearbook 2000). Moscow: Goskomstat, 2000.

Haskel, Jonathan, and Szymanski, Stefan, "Privatization, Liberalization, Wages, and Employment: Theory and Evidence for the U.K.” Economica 60, 238:161-182, May 1993.

Hildreth, Andrew K. G., and Oswald, Andrew J., "Rent-Sharing and Wages: Evidence from Company and Establishment Panels." J. Labor Econ. 15, 2:318-337, Apr. 1997.

Jones, Derek C., "The Economic Effects of Privatization: Evidence from a Russian Panel." Compar. Econ. Stud. 40, 2:75-102, Summer 1998.

Kane, Thomas J., Rouse, Cecilia E., and Staiger, Douglas, "Estimating Returns to Schooling When Schooling Is Misreported.” Working Paper no. 7235. Cambridge, MA: National Bureau of Economic Research, July 1999.

Layard, Richard, and Richter, Andrea, "How Much Unemployment Is Needed for Restructuring: The Russian Experience." Econ. Transition 3, 1:39-58, Mar. 1995.

Lehmann, Hartmut, and Wadsworth, Jonathan, "Tenures That Shook the World: Worker Turnover in Russia, Poland, and Britain.” J. Comp. Econ. 28, 4:639-664, Dec. 2000. 
Lehmann, Hartmut, Wadsworth, Jonathan, and Acquisti, Alessandro, "Grime and Punishment: Job Insecurity and Wage Arrears in the Russian Federation." J. Comp. Econ. 27, 4:595-617, Dec. 1999.

Luke, Peter J., and Schaffer, Mark E., "Wage Determination in Russia: An Econometric Investigation." Working Paper no. 295. Ann Arbor, MI: William Davidson Institute, Mar. 2000.

Megginson, William L., and Netter, Jeffry M., "From State to Market: A Survey of Empirical Studies on Privatization." J. Econ. Lit. 39, 2:321-389, June 2001.

Milanovic, Branko, "Explaining the Increase in Inequality during Transition." Econ. Transition 7, 2:299-341, 1999.

Newell, Andrew, and Socha, Mieczyslaw, "Wage Distribution in Poland: The Roles of Privatization and International Trade, 1992-96.” Econ. Transition 6, 1:47-65, May 1998.

Rose, Richard, "Evaluating Workplace Benefits: The Views of Russian Employees." In Centre for Cooperation with Economies in Transition, The Changing Social Benefits in Russian Enterprises, pp. 39-60. Paris: Organization for Economic Cooperation and Development, 1996.

Rutkowski, Jan, "High Skills Pay Off: The Changing Wage Structure during Economic Transition in Poland.” Econ. Transition 4, 1:89-112, May 1996.

Shleifer, Andrei, and Vishny, Robert W., "Politicians and Firms." Q. J. Econ. 109, 4:995-1025, Nov. 1994.

Slider, Darrell, "Privatization in Russia’s Regions.” Post-Soviet Affairs 10, 4:367-396, Oct.-Dec. 1994.

Tratch, Irina, Rein, Martin, and Wörgötter, Andreas, "Social Assets Restructuring in Russian Enterprises: Results of a Survey in Selected Russian Regions." In Centre for Cooperation with Economies in Transition, The Changing Social Benefits in Russian Enterprises, pp. 95-107. Paris: Organization for Economic Cooperation and Development, 1996.

Vecerník, Jirí, "Changing Earnings Distribution in the Czech Republic: Survey Evidence from 19881994.” Econ. Transition 3, 3:355-371, Sept. 1995. 